\title{
FROM DEMOCRATIC TO AUTHORITARIAN POPULISM: COMPARING PRE- AND POST-2010 HUNGARIAN PENSION POLICIES*
}

\author{
Zoltán ÁDÁM - András SIMONOVITS \\ (Received: 11 May 2018; revision received: 29 July 2018; \\ accepted: 8 August 2018, updated 18 July 2019)
}

\begin{abstract}
We compare the pre- and post-2010 Hungarian political regimes through the lens of pension policies. We label the pre-2010 regime as democratic populist because it was characterized by fiscally irresponsible policies, yet it maintained the system of checks and balances and the rule of law. In contrast, we call the post-2010 regime authoritarian populist as it has employed authoritarian political techniques while maintained popular legitimation through regular elections. To substantiate the difference between the two periods from an economic viewpoint, we compare pre- and post-2010 pension policies to find important differences as well as surprising similarities. In particular, we analysed the following five policy aspects: (a) reform and partial privatization of the governmentrun pension system, (b) policies on the statutory (normal) and the effective (average) pension age, (c) indexation, (d) progression in benefits calculations and progressivity in the personal income tax, and (e) contribution rates. Based on ideological preferences, we argue that one would expect the pension system to become financially more sustainable but less redistributive after 2010 in comparison to the preceding period. Yet, we find that although pro-poor redistribution through the pension system has indeed been curtailed, fiscal sustainability has not improved due to the erratic policies.
\end{abstract}

Keywords: public pension systems, private pension systems, pension policy, authoritarian populism, democratic populism, Hungary

JEL classification indices: H55, J26, P16, P48

* An earlier version of this paper appeared in the discussion paper series of the Institute of Economics, Centre for Economic and Regional Studies, Hungarian Academy of Sciences as MT-DP $-2017 / 31$.

We express our gratitude to Róbert Iván Gál, Gábor Oblath and Péter Tölgyessy for their constructive remarks on previous versions of this paper, as well as to the participants of the 3rd Conference on the Role of the State in Varieties of Capitalism at the Institute of World Economics of the Hungarian Academy of Sciences and the Center for EU Neighborhood Studies of Central European University (Budapest, Nov. 30 - Dec. 1, 2017). Of course, none of them is responsible for any remaining errors.

Zoltán Ádám, corresponding author. Lecturer, Corvinus University of Budapest, Faculty of Economics, Department of Comparative and Institutional Economics, Hungary.

E-mail: zoltan.adam@uni-corvinus.hu

András Simonovits, research fellow emeritus, Institute of Economics, Centre for Economics and Regional Studies, Hungarian Academy of Sciences, Budapest, Hungary and Budapest University of Technology. E-mail: simonovits.andras@krtk.mta.hu 


\section{INTRODUCTION}

A great number of papers have been published on the Hungarian pension system, mostly on its structural reform (partial privatization) started in 1998 (e.g. Simonovits 1999; Augusztinovics et al. 2002; Gál et al. 2008; Guardiancich 2008; Holtzer 2010). But the post-2010 developments have not received sufficient attention and that little investigation is also concentrated on the renationalization of the mandatory private pillar (e.g. Simonovits 2011; Szikra 2014). The present paper discusses policies between 1998 and 2017 from a particular political economic context. Our primary interest is to analyze and interpret the difference between the periods of liberal democracy and autocracy in Hungary in terms of pension policies.

The dividing line between the two periods is 2010, the landslide electoral victory of Viktor Orbán's Fidesz party that brought an authoritarian populist regime (Kornai 2015). The term 'authoritarian populist' here refers to a political regime in which a popularly elected government adopts a majoritarian approach to power, and creates a situation in which its opposition becomes systematically disadvantaged by formal and informal political institutions. Elections continue to be held, but there is a limited chance for a peaceful takeover of power by any contender. Control over public resources is highly centralized, while control over private resources is politically influenced. Extensive clienteles are built, and autonomies of non-governmental actors are constrained (Kornai 2016; Magyar 2016; Müller 2016; Magyar - Vásárhelyi 2017). Orbán, himself, calls this regime 'illiberal democracy'.

This was not the situation before 2010, when Hungary had a liberal democratic regime, in which the peaceful takeover of power took place at least four times between 1990 and 2010. ${ }^{\text {Y }}$ et, populism also played an important role pre-2010, too: continuing the tradition of János Kádár's communist regime ${ }^{2}$, when economic populism was used to buy votes and pacify those who were suffering losses as a consequence of government policies (Benczes 2011). In this paper, we put authoritarian against democratic populism, and seek to demonstrate the difference between them by examining their respective pension policies. By doing this the paper contributes to the literature on contemporary populism (Mudde 2004; Finchelstein 2014; Kriesi - Pappas 2015; Müller 2016; Brubaker 2017; Mudde

1 Elections in 1994, 1998, 2002 and 2010 brought opposition parties into power. Only once, in 2006, was the incumbent government reelected.

2 János Kádár was the First, then the General Secretary of the ruling Hungarian Socialist Workers' Party in 1956-1988. 
- Kaltwasser 2017) and help situate its subject into the empirically examined socio-economic trends.

Pension policies are an ideal subject of political economic analysis as they concern a large part of the electorate. Pension systems are delicate long-term constructions, whose reforms need a lot of political and professional ingenuity (Barr - Diamond 2008). Moreover, in most of the developed world, and especially in the EU11 countries ${ }^{3}$, including Hungary, the future of the pension system is rather dark (Domonkos - Simonovits 2017). Raising of the statutory (normal) retirement age can dampen the impact of rising life time expectancy, but low fertility rates and excessive pension hikes, especially for previous high earners, undermine sustainability. According to various studies, the balance of the Hungarian pension system may turn into negative or very negative in the coming decades, especially from 2035 (e.g. Bajkó et al. 2015 and Freudenberg et al. 2016, respectively), while other studies assert sustainability (Dekkers et al. 2015). In any case, rising emigration from Hungary and the lack of significant immigration into Hungary may place a heavy extra burden on the Hungarian pension system in the foreseeable future.

The structure of the rest of the paper is as follows: In Section 2, we present our argument and hypothesis. In Section 3, we outline the pension policies of the period of democratic populism from the introduction of the three-pillar pension system in 1998 until the two-third electoral victory of Fidesz party in 2010. Section 4 discusses the pension policies of authoritarian populism: the period characterized by the elimination of checks and balances on government authority and the establishment of a manifestly illiberal political regime after 2010. Section 5 provides a comparison of results for the pre- and post-2010 periods and draws conclusions. In addition, an Appendix presents the indexation of pensions between 1993 and 2016.

\section{OUR ARGUMENT AND HYPOTHESES: DIFFERENTIATING BETWEEN DEMOCRATIC AND AUTHORITARIAN POPULISMS}

In 1998, Hungary experienced another replacement of a democratically elected government for the second time in a row. It appeared that democracy as a form of governance had been institutionalized. Hungary was set to join the NATO (1999) and the EU (2004). However, a comparatively low employment rate and a pattern of dual-economy development exposed economic policy making to democratic

EU11 is the group of ex-communist EU Member States: Bulgaria, Croatia, Czechia, Estonia, Hungary, Latvia, Lithuania, Poland, Romania, Slovakia and Slovenia. 
populism. By this we mean that economic policies sheltered large sections of population from market forces, typically associated with large social transfers for pensioners and other politically influential, economically inactive or vulnerable parts of society. Such a political pattern is often associated with clientele building as public resources tend to be distributed along political affiliations. Democratic populism also creates political cycles in fiscal spending as budgetary transfers, which are considered to be primary means to ensure political support that becomes especially intensive before elections. Hence, fiscal sustainability is typically a key issue of democratic populism, fitting the pattern of unsustainable macroeconomic cycles, described by Dornbusch - Edwards (1989) and Sachs (1989) decades ago in the context of the post-authoritarian Latin America. As democratic populists serve the demand of their core electorate, they can hardly afford politically to cut social transfers, including pensions.

Hungary was one of the most salient cases exhibiting populist economic policies before 2010 in the EU11. When general government revenues in percentage of GDP declined from $47 \%$ in 1995 to $42 \%$ in 2005 (then increasing), expenditures jumped above $50 \%$ in 2002, and had kept hovering around at that level until 2016. As a consequence, large fiscal deficits had been created in both the 1990s and the 2000s, following a political cycle until post-2006 elections when consolidation was not any more avoidable. Meanwhile, public and foreign debts grew

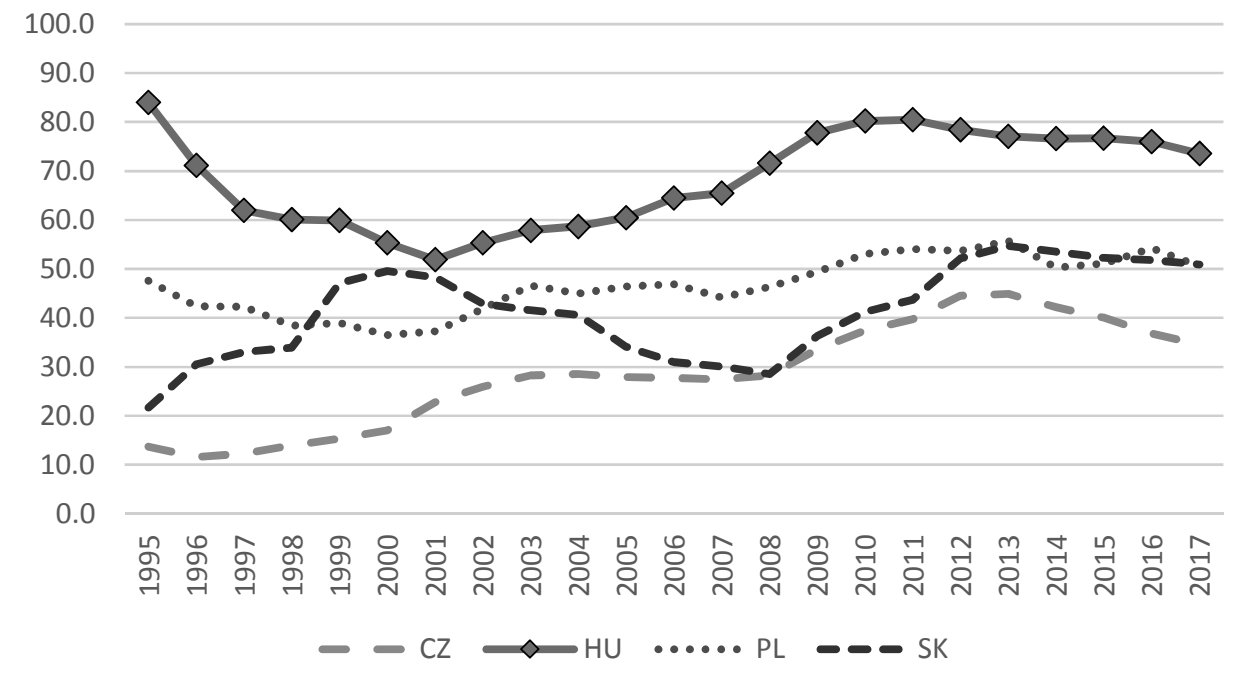

Graph 1. General government consolidated gross debt in per cent of GDP in four countries Source: Eurostat. 


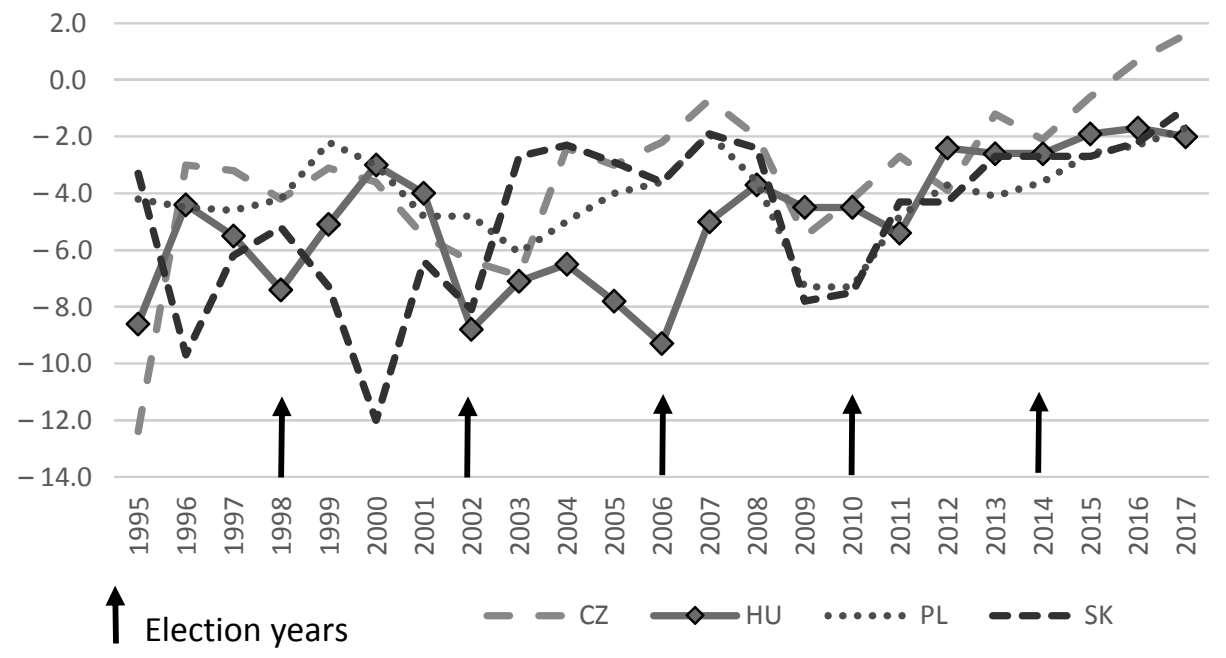

Graph 2. General government net lending/borrowing in per cent of GDP in four countries Source: Eurostat.

considerably, making Hungary one of the most vulnerable countries to the global financial crisis of 2008-2009 (Graphs 1-2)4.

Budgetary overspending was a reaction to the long-standing political demand of the electorate, inherited from the pre-democratic period, in which political conflict was mitigated by compensating losers of public policies (Kornai 1996b). Liberal reformers and international financial institutions, including the IMF and the World Bank, in response, advocated a reform of public services, including pensions. 'Structural reforms' in this context were meant to make governments more autonomous from political pressure, and help to attain more balanced fiscal positions in the long run. In the pre-2010 democratic populist Hungary, reforms and budgetary overspending complemented each other, and created political cycles in both fiscal policy and structural reforms. One of the most salient cases of structural reforms was the pension reform of 1997-1998, generating high hopes and delivering poor results in terms of sustainability (Simonovits 1999, 2011; Guardiancich 2008), to which we will return in Section 3.

An alternative response to the political trap of budgetary overspending is authoritarian populism. This can be introduced with or without structural reforms: the strategy is to redistribute to the benefit of the (higher) middle classes and to constrain effective political choice so that opposition and socially cost-

For a better clarity we illustrate the changes only for Czechia, Hungary, Poland and Slovakia. 
ly policy measures can be paralyzed. This is the typical political response of post-democratic governance in crisis-ridden societies, in which transaction costs of democratic political exchange become too high to bear in the face of diminished expected social utilities. Authoritarian populism can be conceptualized as an alternative to democratic populism as it serves popular political demand by employing authoritarian political techniques, centralizing political control, organizing key societal actors into government sponsored vertical clienteles, and redistributing to their benefits (Ádám 2018).

Essentially, this is what happened in the post-2010 Hungary, when the centre-right Fidesz party altered the entire constitutional system, resulting in the abolishment of effective checks and balances on government power (Tóth 2011; Bozóki 2015; Kornai 2015; Vörös 2015; Halmai 2017). Budget deficits became substantially smaller due to the elimination of the fiscally costly pension reform of 1998, levying special taxes on banks and other multinational-dominated industries, a hike in VAT, and an effective cut in family and childcare allowances. In sum, spending on social protection and general public services decreased, whereas budgetary spending with an economic function ${ }^{5}$ in per cent of GDP - a key vehicle on clientele building - increased after 2010 .

To be sure, the crisis of liberal democracy is a global issue. From Poland to the United States, from Venezuela to Turkey, from Austria and France to Indonesia and the Philippines, the authoritarian populists have come to the fore, offering simple solutions to complex problems and uncertainties (Müller 2016). This paper, however, is devoted to a single case: Hungary. To substantiate our argument on the difference between democratic and authoritarian populisms, we compare pension policies employed in the pre- and post-2010 Hungary. Our analysis concentrates on five dimensions of the Hungarian pension system: (a) The creation and subsequent nationalization of the mandatory private pillar (19982011); (b) The tension between raising statutory retirement age and stagnating effective retirement age (i.e. the lack of strong reduction of benefits for early retirement until 2009, Females40 and of the elimination of early retirement after 2010); (c) The erratic practice of pension indexation during the entire period together with the introduction and the elimination of the $13^{\text {th }}$ month pensions in 2002-2009; (d) Income redistribution through pensions; (e) The arbitrary rise and reduction of contribution rates.

In our hypotheses, we expected the pre- 2010 pension policies (i) to enhance (or at least not to constrain) the scope of individual choices, (ii) to struggle with raising effective retirement age and punishing early retirement, (iii) to index pensions according to the electoral needs, (iv) to redistribute income through pen-

5 Items in 04 - Economic affairs in Eurostat's COFOG classification. 
sions to the benefit of the relatively poor, and (v) to decrease contribution rates to the detriment of fiscal sustainability. In turn, we expected the post-2010 pension policies (i) to constrain individual choices, (ii) raising effective retirement age and punishing early retirement with little political problem if needed, (iii) to provide a degree of stability and predictability in indexation, (iv) not to use pensions to redistribute income to the poor, and (v) not to have much political problems with decreasing contribution rates to obfuscate the public.

\section{THE PERIOD OF DEMOCRATIC POPULISM: PENSION POLICIES IN 1998-2010}

Between 1989 and 2001, Hungary was a front-runner of economic transition. It was among the first post-communist countries to liberalize foreign trade, invite foreign direct investment, privatize strategic industries, and to harden the soft budget constraint of the corporate sector (Kornai 1995; EBRD 1999). It was also the first country in Central and Eastern Europe (CEE) to create a three-pillar pension system in 1998, following the advice of the World Bank (1994).

The reform was introduced after the success of the macro-stabilization of 1995-1996 (Kornai 1996b). It was a swift political process by a coalition of the socialist and the liberal parties, ignoring the critics and opposition, both political and professional. The reform was pushed through parliament in 1997 and was introduced in 1998, a few months before the general elections. Although it was politically popular, the parties of the opposition never subscribed to it, and they started undermining the three-pillar pension system as soon as they assumed office in the Summer of 1998.

The Hungarian version of democratic populism had been characterized by recurring budget deficits and unsustainable fiscal trajectories. A major reason for this was the pressure to maintain fiscal transfers towards politically important groups, such as pensioners. The goal of the pension reform from a political economic perspective was to cut this dynamics by creating private incentives to accumulate long-term savings, and to enforce efficiency criteria on private pension funds. In actual terms, however, no efficient market for long-term savings was produced and the operation of private pension funds was characterized by excessive costs. Other aspects of the pre-2010 pension system were a low and only slowly upward-adjusting effective pension age, erratic changes in indexation, the unsustainable provision of the so-called $13^{\text {th }}$ month pension in 2003-2009, and considerable pro-poor redistribution. 


\subsection{Partial privatization}

The Hungarian mandatory private pension system was created in a very short period of time in 1997-1998. This was a classic three-pillar system advocated by the World Bank and other experts globally during the privatization frenzy of the 1990s. The three pillars were as follows: (i) a traditional pay-as-you go pillar, operated by the government-run social security system, (ii) a mandatory private pillar, introduced in 1998, and (iii) a voluntary private pillar that had actually existed since 1993, but remained small and structurally insignificant, and thus we shall neglect it in our discussion.

Hence, effectively, until 1998, Hungary had a purely unfunded (monopillar) public pension system. This was a strongly progressive system (Augusztinovics Martos 1996), especially, if we take into account that the personal income tax was also quite progressive. Since then, the impact of the number of contribution years remains progressive.

Importantly, in the context of the 1998 reform, the remaining public pillar was set to be transformed into a defined contribution (DC) system, in which the formerly loose link between contributions and benefits were to be transformed into a strong one, but the actual benefits were to be still paid out from current revenues. At the start, about half of the workers entered voluntarily into the mixed system; and by 2010 another quarter of the workers (those entering the labour force between 1998 and 2010) had to join but a large share of them would have also joined voluntarily.

Since the cost of transition to this mixed system was financed from public debt, the budget deficit was much higher and the government debt rose much faster than it would have been without this structural reform (Drahokoupil - Domonkos 2012; Casey 2014). Though it is impossible to separate out the impact of various public policies on debt dynamics, the fact is that the government debt ratio rose from $52 \%$ (at the end of 2001) to $66 \%$ (at the end of 2007) to continue to $80 \%$ (at the end of 2010). The third figure already contains the steep depreciation of the nominal exchange rate and increased foreign exchange reserves in the context of the EU-IMF-World Bank financing package obtained in November 2008.

\subsection{Statutory versus effective retirement age}

A key issue of any pension system is the dependence of the annual benefit on the retirement age. A sensible system emulates a private saving scheme: the longer one accumulates her own annual contribution, the more virtual capital is accumulated, and the fewer parts it should be divided into (because she lives fewer inactive years). 
Traditionally, in all communist countries, the statutory retirement age was relatively low: 55 for women and 60 for man. (Life expectancy, especially for males, was also low prior to 1989 mainly due to high mortality between age 20 and 40.)

When full employment collapsed during the transition and open inflation appeared, the out-dated pension system had to be modernized. Life expectancy also started to rise from the early 1990s. As a natural reaction, in 1996, statutory retirement age was raised to 62 by 2001 and 2009 for males and females, respectively. Due to the exaggerated fear of mass unemployment, however, subsequent governments maintained the possibility to obtain disability pensions easily. Furthermore, the benefit reduction for early retirement remained very modest, especially for those who had a relatively long period of contribution (Vanhuysse 2006). It is small wonder that in spite of the rising statutory retirement age, the effective retirement age hardly rose.

Another problem appeared with respect to fragmented careers (Augusztinovics - Köllö 2009; Dekkers et al. 2015). To measure the weak link between the retirement age and the length of contribution, Granseth et al. (2016) used a relatively simple indicator, namely the correlation between retirement age and the length of contributions. This indicator becomes positive in well-designed pension systems (e.g. Sweden), while it is negative in poorly designed systems (e.g. Hungary).

When the Great Recession arrived in 2008, the centre-left Hungarian government sought to strengthen the sustainability of the pension system by raising the statutory retirement age from 62 to 65 by 2022, and allow early retirement only with sensible reductions.

Table 1 displays the outcomes for the period of 2006-2010. In 2007, 101\% of males of the cohort size retired $(50,900 / 50,300)$, while in 2008 , only $54 \%$ $(25,700 / 47,400)$ retired. The reason was simple: males (and females) wanted to avoid the sudden decrease of $8 \%$ in the initial pensions announced for 2008 . (This was part of the post-2006 fiscal stabilization efforts that preceded the cancellation of the $13^{\text {th }}$ month pension in 2009.)

Table 1. Retirement ages and relative sizes: males and females, 2006-2010

\begin{tabular}{l|c|c|c|c}
\hline \multirow{2}{*}{ Year } & \multicolumn{2}{|c|}{ Males } & \multicolumn{2}{c}{ Females } \\
\cline { 2 - 5 } & $\begin{array}{c}\text { Average retirement } \\
\text { age (year) }\end{array}$ & $\begin{array}{c}\text { Relative } \\
\text { size }\end{array}$ & $\begin{array}{c}\text { Average retirement } \\
\text { age (year) }\end{array}$ & $\begin{array}{c}\text { Relative } \\
\text { size }\end{array}$ \\
\hline 2006 & 59.9 & 0.638 & 57.5 & 0.758 \\
\hline 2007 & 59.7 & 1.012 & 57.8 & 1.028 \\
\hline 2008 & 59.8 & 0.542 & 57.3 & 0.611 \\
\hline 2009 & 59.7 & 0.727 & 59.9 & 0.239 \\
\hline 2010 & 60.2 & 0.676 & 60.7 & 0.198 \\
\hline
\end{tabular}

Source: Fazekas - Varga (2015: 262, Table 11.5) 


\subsection{Indexation and extra benefits}

In modern economies, public pensions in progress are indexed, i.e. each year their nominal values are increased in a prescribed way. There are two pure types of indexation: every year the pension benefits increase with the rate of either the wage increase or the price increase. There are a number of combinations of the two pure types, among which the most widespread one is the $50-50 \%$ combination that is also known as "Swiss indexation". In the early years of transition (between 1989 and 1996), when real wages decreased by cc. $20 \%$, wage indexation was used to relieve the pension budget (Table A.1 in Appendix). It has the advantage that the relative value of the benefit in progress to the nationwide average wage remains invariant to the number of years passed after retirement.

When the Hungarian GDP and real wages started to increase steadily, policy makers realized the burden of preserving wage indexation. They could have introduced price indexation, with the advantage of preserving the real value of the benefit in progress when the nationwide average real wage decreases, but they carefully chose combined indexation. This way, the general government saved a lot: With a given initial pension and a steady annual nationwide average real wage increase of $2 \%$, the wage indexation would have cost by cc. $10 \%$ more than the combined indexation did. Hence, the combined indexation preserved both the relative and the real stability of pensions but in a limited way. In sum, since 1999, the Hungarian pension law has prescribed expected indexation; combined wage - price indexation until 2009, and pure price indexation since 2010.

There have always been various tricks to raise or diminish pension benefits in Hungary, but a very visible form of rise was the introduction of the so-called $13^{\text {th }}$ month pensions between 2003 and 2006 by the centre-left government of 2002-2006. This somewhat counterbalanced the impact of the reduced indexation introduced in 2000 by the centre-right government, but it also raised the government pension expenditure by $8.3 \%$ with respect to the original calculations, and upset the balance between the pay-as-you-go and the mandatory private pension pillars. ${ }^{6}$ Although the $13^{\text {th }}$ month pension was a popular policy measure, it was cancelled altogether in 2009 in the context of the loan agreement Hungary made with the EU, the IMF and the World Bank after the outbreak of the global financial crisis. In consequence, the $13^{\text {th }}$ month pensions became an experience of short lived extraordinary pension hike, whose reintroduction is a recurring populist political theme, both on the left and right.

$6 \quad$ Fidesz party promised the introduction of a $14^{\text {th }}$ month pension in their 2006 election manifesto, but lost the elections against the Socialists. 


\subsection{Redistribution in pensions}

Though the bulk of the pensions one receives are pension in progress, every pension had started as an initial pension. There are two pure types of initial public pensions: (i) flat benefits and (ii) defined contribution benefits (for short, DC). Both have subtypes: ad (i) whether the benefit depends on the number of years of contribution or not; and ad (ii) whether the benefit depends on earnings in all or the latest years of employment. In practice, most countries operate a combination of the two pure types.

Hungary has been operating a very complex system, where progress in the lifetime average of net wages plays a prominent role, and the initial pension is proportional to the average of the valorised net wage of each year between 1988 (the last year of socialism) and the year of retirement. To avoid superfluous details, we can approximate the degree of redistribution by a scalar which determines the share of the flat part in the combination (Disney 2004). For example, if we approximate a pension system as the linear combination of the flat and the proportional components, then our claim becomes obvious.

Hungary started the post-communist transition with a doubly progressive pension formula: (i) the very progressive personal income taxation that made net wages a very compressed function of gross wages and (ii) the pensions were a very compressed function of net wages. To make the remaining public pillar also DC-type by 2013, when the first private life-annuity was planned to be paid out, the pension progressivity described in (ii) was practically phased out by 2009 . (While in 1998, a large part of the new pensions were diminished by this rule; in 2009, there were hardly any.) The progressivity of the benefit - contribution length schedule was also planned to be replaced by a proportional scale by 2013 . For example, as a survivor from the early days of public pensions, in 1998 the first 20 years of employment still gave $53 \%$ of the total benefit out of the total $80 \%$ implied by 40 years of employment, this was planned to be reduced to $40 \%$. But in the turmoil of the post-2010 years, it was forgotten.

In sum, the pre-2010 pension system had started off as a strongly progressive regime in which considerable redistribution from high earners with long careers to low earners with short careers took place through both net wages and pensions. As the pension system was reformed and the progressivity of personal income taxation was reduced, whereas the remaining public pillar's defined contribution character was to be ensured after the partial privatization in 1998, the degree of redistribution was considerably cut back by 2009 . 


\subsection{Contribution rates}

Ideally, expenditures of government-run, mandatory pension and health systems are financed from contributions. In well-run countries, other sources of revenues may also finance social security expenditures but this requires much stronger budgetary discipline as has been the rule in Hungary. Contributions to the two parts of the social security system - pensions and public healthcare - are also broken up into the ones paid by employees and employers. These four rates (pension, health / employee, employer) kept changing during the entire period. Because of the permanent restructuring of various pensioner categories, it is difficult to keep track of all the changes. With the carving out of the mandatory private pillar in 1998, financed from employee pension contributions, an apparent deficit called transition cost arose in the public pension pillar. To have an idea of its size, it is important to note that it reached 1.3\% of GDP per annum by 2009 .

Another issue was the cap on the contribution base. To limit annual pension benefits, as in most other countries, in Hungary too, there was a cap on employees' contribution base between 1992 and 2012. In 2009, the total amount of the above-cap employees' contribution was less than $2 \%$ of the total pension contributions, much lower than the corresponding employers' contributions - that was never capped - amounting to $5 \%$. At the cost of some simplifications, we can consider as if this $5 \%$ were transferred from the above-cap pensioners to the below-cap ones. This is because although employers did pay these above-cap contributions to the pension system after their high-earner employees, the latter had derived no benefits from them. Hence, the employer's contributions had also delivered some degree of solidarity in the pre-2010 pension system.

\section{THE PERIOD OF AUTHORITARIAN POPULISM: PENSION POLICIES IN 2010-2017}

Gaining $53 \%$ of the votes given to party lists, the centre-right Fidesz party obtained $68 \%$ of the parliamentary seats at the 2010 elections due to the highly distortionary Hungarian election system. With its two-third majority, Fidesz was able to change the entire constitutional system. It did so systematically, eliminating all meaningful checks and balances on government power, including the effective independence of the Constitutional Court, subordinating the public media, and exercising explicit political influence on private media outlets. The relative independence of government agencies was effectively suspended by appointing loyal friends, often for unprecedentedly long tenures. Professional ethos of civil servants got destroyed by the new legislation making hiring and firing a discre- 
tionary right of the political appointees. Election rules were changed to the benefit of Fidesz, while public funds have been heavily used in clientele building and to conduct permanent political campaigns (Bozóki 2015; Kornai 2015; Freedom House 2016).

Democratic populism was associated with unsustainable economic policies, but it did not seek to constrain political competition. Generally, it respected the rule of law, and usage of public funds for private political means, although existed, was much more modest than after 2010. In contrast, since 2010, authoritarian populism has dismantled the rule of law and created a new highly centralized system of resource allocation that still provides fiscal transfers to politically important social groups, such as pensioners, along with large scale government-created rents enjoyed by the members of the business clientele (CRCB 2016).

Now the question is whether we can differentiate between democratic and authoritarian populisms at the policy level, with particular reference to the pension policies. Having presented the pension policies in the period of democratic populism in 1998-2010, now we turn to the post-2010 period of authoritarian populism, once again touching upon the five dimensions of pension policy we discussed in Section 3.

\subsection{Renationalization}

When the newly elected prime minister, Viktor Orbán flew to Brussels in May 2010, he first tried to convince the European Commission to open the door to relaxing the budget. When this request was denied, the new government had only days to work out a new economic program. After some trials, as the simplest solution to enlarge its manoeuvring room, in late 2010 the government renationalized the mandatory private pillar. During their existence, the private pension funds worked with so high cost (World Bank 2006; Guardiancich 2008) that there was practically no political opposition to their closure (Simonovits 2011). As a result, the annual budget deficit-to-GDP ratio immediately dropped by $1.3 \%$ and the nationalization of assets of the mandatory private pillar opened a room to the reduction of public debt by about $10 \%$ of GDP.

The government dared not to simply close down the mandatory private pillar, rather, a new law was enacted which offered two options: either (i) a member returns to the monopillar and can cash in the positive real yields accumulated on his/her account (on average, amounting to a modest $7 \%$ of the capital) or (ii) he/she stays in the private pillar, and after a one-year break, can restart his/her employee's contributions (of $10 \%$ of his/her gross wages) to the private account but his/her future employer's contribution (of $24 \%$ of the gross wage) stops in- 
creasing his/her prospective public benefit. As a result, $97 \%$ of the members of the mandatory private pillar returned to the monopillar system.

The remaining $3 \%$ of the erstwhile members (holding $10 \%$ of the original total capital) successfully resisted the government and, within a year, the parliament adopted a new legislation. Therefore, the remaining members were not allowed to restart contribution to their private accounts but their entire contribution (34\% of the gross wages, paid by employees and employers combined) continued to be forwarded to the monopillar system and kept earning additional public pension rights. (Until now, however, there is only an incomplete law determining the rules of paying private benefits at retirement for them.)

Opposition parties claimed that the government stole people's savings accumulated on their private pension accounts. Being afraid of an economic collapse and/or the nationalization of bank accounts, many Hungarian citizens transferred their ordinary private savings into foreign bank accounts. Meanwhile in its Convergence Report 2018-2021, the government claimed that by closing down the mandatory private pension pillar, it diminished and keeps diminishing the government debt. However, as if the Report's authors have not heard about the transformation of explicit into implicit debt, no mention on the rise in implicit public debt (as a result of growing benefit claims) can be found in the Report.

At the end of this Subsection, we cite four numbers on the share of the public pension system in proportion to GDP in 2011. With expenditures on pensions at $10.8 \%$ of GDP, Hungary fell between the minimal Lithuanian (7.6\%) and the maximal Polish $(11.3 \%)$ ones within the EU11 (post-communist countries that have joined the EU), and all these three countries are well below the EU28 average (12.6\%) (Domonkos - Simonovits 2017, Table 2). It is also noteworthy that by transferring disability pensions from the public pension system to another category, frontline pension expenditures were cut to $9.4 \%$ of GDP in 2012. These unusual measures have contributed to hiding the real problems of the Hungarian pension system.

\subsection{Females40 \& rigid retirement age}

In its election program of 2010, Fidesz made a promise that women who have accumulated at least 40 years of rights before reaching the statutory retirement age will be allowed to retire with full benefit (Females40). While the initial pension benefit still depends on the number of years of contributions, and the years spent in vocational school or in higher education (before 1998) are counted as the contribution period, the years of rights exclude them. These qualifications did not work out, probably because a lot of employees study on a part-time basis in vo- 
cational schools or higher education besides work. As a result, since the introduction of Females 40 in 2011, more than $50-70 \%$ of the newly retired females have been using this exit route, with the actual average retirement age much below the steeply rising statutory retirement age.

Perhaps as a countermeasure, since 2012 no other early retirement has been allowed, not even with actuarially fair benefit reduction. The channels of disability retirement were significantly narrowed down as well, raising concerns with respect to the dignity of beneficiaries (Szikra - Kiss 2017). The publicly available statistics of the Hungarian Pension Office - ONYF - (2012-2016) as well as the analyzis of Czeglédi et al. (2017) demonstrate the inefficiency and inequity resulting from the introduction of Females 40 and the elimination of the possibility of early retirement.

By staying content with the simplest numerical calculations, we compare two women in 2016: One acquired 40 years of rights and retired at the age of 58 with full benefit, i.e. $80 \%$ of her valorised average net wage. The other woman wants to retire at age 62.5 with 39 years of rights but she cannot because, from 2016, the statutory retirement age is 63 years. In a sensible flexible pension system, the government would deduct $5.5 \times 6=33 \%$ of the full benefit from the first woman, i.e. she would receive $53.6 \%$ of her net wage, while the second woman would obtain $0.39 \times 0.02 \times(1-0.06 \times 0.5)=75.7 \%$ of her net wage.

With the current steep rise in net value of average real wages, Females40 has become a boomerang (Simonovits 2019). To illustrate our point, we replace the second woman with a third one, who retired in 2019 rather than 2016. Working three years longer, she forsaked three years pension but increased her annual benefit in real terms by $1.074 \times 1.102 \times 1.08 \times 1.075=1.374$. $(1.074,1.102$ and 1.08 are the annual real growth factors of the average net wages, while 1.075 is the effect of working for 43 rather than 40 years.) As a result, her total benefits in real terms rose from $20 \times 100=2,000$ units to $17 \times 1,374=23,360$ units!

It is also worth presenting some data on real outcomes. Table 2 displays the characteristics of males, females and Females40 between 2010 and 2014. The outcome is chaotic: the relative size of newly retired cohorts developed erratically, whereas the tendency for early female retirement had continued.

\subsection{Overindexation and relative devaluation}

On the one hand, pensions were considerably over-indexed in 2013-2016 with respect to the law (Table A.1 in Appendix). Anticipating the falling global energy prices and delivering a popular policy measure before the 2014 elections, the Fidesz government administratively forced a significant household energy price 
Table 2. Retirement ages and relative sizes: males, females and Females40, 2010-2014

\begin{tabular}{l|c|c|c|c|c|c}
\hline \multirow{2}{*}{ Year } & \multicolumn{2}{|c|}{ Males } & \multicolumn{2}{c|}{ Females } & \multicolumn{2}{c}{ Females40 } \\
\cline { 2 - 7 } & $\begin{array}{c}\text { Average } \\
\text { retirement } \\
\text { age (year) }\end{array}$ & $\begin{array}{c}\text { Relative } \\
\text { size }\end{array}$ & $\begin{array}{c}\text { Average } \\
\text { retirement } \\
\text { age (year) }\end{array}$ & $\begin{array}{c}\text { Relative } \\
\text { size }\end{array}$ & $\begin{array}{c}\text { Average } \\
\text { retirement } \\
\text { age (year) }\end{array}$ & $\begin{array}{c}\text { Relative } \\
\text { size }\end{array}$ \\
\hline 2010 & 60.2 & 0.676 & 60.7 & 0.198 & & \\
\hline 2011 & 60.3 & 0.753 & 58.5 & 1.194 & 57.6 & $0.769^{*}$ \\
\hline 2012 & 62.0 & 0.365 & 59.1 & 0.727 & 57.8 & 0.374 \\
\hline 2013 & 62.2 & 0.356 & 59.5 & 0.544 & 57.8 & 0.329 \\
\hline 2014 & 62.2 & 0.249 & 59.3 & 0.484 & 58.2 & 0.360 \\
\hline
\end{tabular}

Sources: As Table 1. *Oral communication: The number for Females40 in 2011 also contains those who retired earlier but were reclassified in 2011.

cut on energy retail suppliers. Willy-nilly, these price reductions were left out in the official annual consumer price forecast between 2013 and 2016, therefore the actual cumulative price increase was by about $8.6 \%$ lower than the forecast. This way, the price-indexed pensions had increased by $8.4 \%$ in real terms, celebrated by the government propaganda as the revival of the $13^{\text {th }}$ month pensions.

Very few experts and politicians have dared to criticize this 'achievement', and more and more citizens consider the pension expenditure as a free good. Critical voices only underlined that those who retired later than the process started received only a part or zero pension increase.

It is an example of the arbitrariness of indexation that by the end of 2016 the government gave an extra uniform additional benefit amounting to $8 \%$ of the monthly (i.e. $0.7 \%$ of the annual) average pension. In 2017 (2018 was an election year!), the government repeated this and also gave a pension bonus.

On the other hand, from 2016, a drastic U-turn happened in the Hungarian wage and benefit dynamics. As already mentioned in Subsection 4.2, real wages exploded, while the bulk of pensions stagnated in real terms. As a result, the average replacement rate (the ratio of net pensions to net wages) dropped from 0.668 to 0.550 , relatively devaluing benefits to wages. This process temporarily opens room for a drastic reduction of the pension contribution rate, reinforcing the rise of the net wages. It is only a question of time, however, when the whole process reverses itself (Simonovits 2018).

\subsection{Polarization of initial pensions}

As mentioned in Subsection 3.4, until 2010, the personal income tax was rather progressive with significant earned income tax credit (diminishing the lowestearners' personal income tax obligations) and two marginal tax rates around $20 \%$ 
and $40 \%$. Since $2011 / 2012$, it is a proportional (flat rate) income tax, earlier with $16 \%$, currently with $15 \%$ rate. Each year since 2011 , low earners have been paying relatively more tax than before 2011, whereas high earners have been paying relatively less tax than before. Consequently, with passing time, the low new pensions become lower, and the high new pensions become higher, resulting in a considerable polarization of pensions. To give two simple examples: (a) Consider a worker with a minimum wage. He/she has not paid any personal income tax between 2003 and 2010, while now he/she pays $15 \%$ of his/her gross wage. Though the gross nominal minimum wage grew a lot, the corresponding real value of the net wage hardly rose between 2010 and 2016. (b) Consider another employee, who earns three times the average wage (close to the cap on the employee's pension contribution base around 2010). Before the personal income tax reform of 2011 , he/she paid as a tax cc. $40 \%$ of his/her gross wage above the average, now he/she pays only $15 \%$. $^{7}$

Table 3 reports the wildly diverging relative real household incomes of the average, the lowest and the highest deciles in Hungary between 2010 and 2015. While the average real income dropped from 100 (2010) to 95.7 (2012), and jumped to 109 (2015), the lowest decile's indicator dropped from 31.8 (2010) to 27.7 (2012), and only returned to its initial value in 2015. The highest decile's indicator oscillated but eventually grew from 231.1 to 259 .9. It is an open question how much these numbers are sensitive to the changing degree of tax evasion and imperfect observations.

An especially wild form of the pension polarization, connected to the elimination of the annual cap, is visible even to the ordinary citizen. As the number of cap-less years rises, more and more pensioners receive a benefit above the

Table 3. Real incomes: lowest vs. highest deciles, 2010-2015

\begin{tabular}{l|c|c|c}
\hline Year & Average & $\begin{array}{c}\text { Lowest } \\
10 \%\end{array}$ & $\begin{array}{c}\text { Highest } \\
10 \%\end{array}$ \\
\hline 2010 & 100.0 & 31.8 & 231.1 \\
\hline 2011 & 101.2 & 31.7 & 234.5 \\
\hline 2012 & 95.7 & 27.7 & 228.7 \\
\hline 2013 & 99.1 & 28.6 & 242.2 \\
\hline 2014 & 104.1 & 30.0 & 250.4 \\
\hline 2015 & 109.0 & 31.6 & 259.9 \\
\hline 2016 & 113.2 & 31.7 & 270.1 \\
\hline
\end{tabular}

Source: Yearbooks of the Hungarian Statistical Office.

7 Note that in Hungary, the pension benefits are calculated from net wages and are exempted from personal income taxation. 
mythical value of one million forints (cc. 6 times the average net wage or cc. 8 times the average net pension).

\subsection{Contribution rates}

The full version of the present paper (in Tables 5 and 6 of Ádám - Simonovits 2017) depicted the rounded-off values of the corresponding contribution rates in 2016 and 2017, respectively. Here, we only report the final data. While the initial total contribution rate (pension and health, employer and employee combined, in terms of gross wage) of $44 \%$ is generally considered very high, international comparisons do not support this view (for example, in Slovakia, this figure is $48 \%$ ). Confining attention to the total pension contribution rate, note that in a single year, it decreased from $32 \%$ to $26 \%$. It is easy to see that the radical reduction, which was forced through parliament in a rush, only six months after the acceptance of the budget for 2017, diminished the first factor of the revenue product to $(26 / 32=) 81.25 \%$. To counteract this drop, the second factor, the aggregate wage should increase at least to $(32 / 26=) 123.1 \%$. Though the wage growth has been quite fast since 2016 , and the total pension contribution is only $22.5 \%$ since July 2019 , this reduction will ceteris paribus increase the general government deficit, and, hence, will prevent from increasing expenditures on other budgetary functions, such as much-neglected health care. (The unexpected delay of the latest reduction of 2019 from January to July already signals tensions.)

\section{DISCUSSION AND CONCLUSIONS}

We have compared pension policies pursued by Hungarian governments in the period of democratic populism of 1998-2010, and in the period of authoritarian populism of 2010-2017. In the first period, incoherent pension policies were followed: the carved-out mandatory private pillar had not delivered the promised fruits, the rise in the statutory retirement age was only partially followed by the rise in average retirement age, and the partial elimination of redistribution increased high initial pensions, whereas indexation remained haphazard, including the introduction and elimination of the $13^{\text {th }}$ month benefits during 2003-2009. Hence, our empirical results confirmed our hypotheses with respect to the 19982010 period: the pension policies were erratic and served short-term electoral demands without offering long-term solutions for structural problems.

The pension policies of the post-2010 period have a different story. By renationalizing mandatory private pension funds arrogantly, the contributors were 
intimidated and the spirit of the rule of law weakened. Long-term fiscal sustainability, however, was not improved but - taking into consideration the implicit debt towards future pensioners - deteriorated. Effective retirement age has not risen sufficiently as a consequence of Females40, even if other options of early retirement - irrationally enough - were eliminated. As over-indexation of pensions became a fixture of the government's pension policy, it would be hard to argue that stability and predictability were enhanced with respect to the indexation either. Moreover, the recent cuts in contribution rates have probably also weakened the long-term sustainability of the pension system, contradicting our hypothesis of attaining more stable and reliable financial positions through the maintenance of contribution rates. In turn, with the elimination of progressive income taxation and of the progression in pensions, pro-poor income redistribution through pensions was reduced after 2010, in line with our expectations.

Nevertheless, neither the elimination of the mandatory private pension funds and the resulting short-term windfall revenue in government budget, nor the declining income redistribution through the pension system have been associated with improved financial sustainability. Instead, the subordination of society to illiberal policies has been carried out, symbolized by the forced nationalization of the mandatory private pension funds, demonstrating a limited rule of law and the vulnerability of private property to a constitutionally unconstrained government.

\section{REFERENCES}

Augusztinovics, M. - Gál, R. I. - Matits, Á. - Máté, L. - Simonovits, A. - Stahl, J. (2002): The Hungarian Pension System before and after the 1998 Reform. In: Fultz, E. (ed.): Pension Reform in Central and Eastern Europe, Vol. 1-2, Geneva: International Labour Office, pp. 25-93.

Augusztinovics, M. - Köllö, J. (2009): Decreased Employment and Pensions. The Case of Hungary. In: Holzmann, R. - MacKellar, L. - Repansek, J. (eds): Pension Reform in Southeastern Europe. Linking to Labor and Financial Market Reform. Washington, D.C.: World Bank, pp. 89-104.

Augusztinovics, M. - Martos, B. (1994): Pension System: Calculations and Conclusions. Acta Oeconomica, 48 (1-2):119-160.

Ádám, Z. (2018): Authoritarian Populism at Work: A Political Transaction Cost Approach with Reference to Viktor Orbán's Hungary. UCL Centre for Comparative Studies of Emerging Economies (CCSEE), Working Paper Series, No. 2.

Ádám, Z. - Simonovits, A. (2017): From Democratic to Authoritarian Populism. Comparing Preand-Post-2010 Hungarian Pension Policies. Budapest: IE-CERS-HAS Working Paper, No. 31.

Bajkó, A. - Maknics, A. - Tóth, K. - Vékás, P. (2015): On the Sustainability of the Hungarian Pension System (in Hungarian). Közgazdasági Szemle, 62 (December):1229-1257.

Barr, N. - Diamond, P. (2008): Reforming Pensions: Principles and Policy Choices. Oxford: Oxford University Press.

Benczes, I. (2011): Market Reform and Fiscal Laxity in Communist and Post-Communist Hungary. A Path-Dependent Approach. International Journal of Emerging Markets, 6(2): 118-131. 
Bozóki, A. (2015): Broken Democracy, Predatory State and Nationalist Populism. In: Krasztev, P. - Til, J. von (eds): The Hungarian Patient: Social Opposition to an Illiberal Democracy. Budapest: CEU Press, pp. 3-36.

Brubaker, R. (2017): Between Nationalism and Civilizationism: The European Populist Moment in Comparative Perspective. Ethnic and Racial Studies, 40(8): 1191-1226.

Casey, B. H. (2014): From Pension Funds to Piggy Banks: (Perverse) Consequences of the Stability and Growth Pact since the Crisis. International Social Security Review, 67(1): 27-48.

CRCB (2016): Competitive Intensity and Corruption Risks. Statistical Analysis of Hungarian Public Procurement - 2009-2015. Data and Descriptive Statistics. Budapest: Corruption Research Center.

Czeglédi, T. - Simonovits, A. - Szabó, E. - Tir, M. (2017): What is Wrong with the Hungarian Pension Rules? Acta Oeconomica, 67(3): 359-387.

Dekkers, G. - Desmet, R. - Rézmovits, Á. - Sundberg, O. - Tóth, K. (2015): On Using Dynamic Microsimulation Models to Asses the Consequences of the AWG Projections and Hypotheses on Pension Adequacy: Simulation Results for Belgium, Sweden and Hungary. Brussels - Budapest: ONYF. mikroszimulacio.onyf.hu=goo.gl/U28Wka.

Disney, R. (2004): Are Contributions to Public Pension Programmes a Tax on Employment? Economic Policy, 19(39): 267-311.

Domonkos, S. - Simonovits, A. (2017): Pension Reforms in EU11 Countries: An Evaluation of Post-Socialist Pension Policies. International Social Security Review, 70: 109-128.

Dornbusch, R. - Edwards, S. (1989): Macroeconomic Populism in Latin America. Working Paper, No. 2986. Cambridge, MA: National Bureau of Economic Research.

Drahokoupil, J. - Domonkos, S. (2012): Averting the Funding-Gap Crisis: East European Pension Reforms since 2008. Global Social Policy, 12(3): 283-299.

EBRD (1999): Transition Report 1999. Ten Years of Transition. London: European Bank for Reconstruction and Development.

Fazekas, K. - Varga, J. (eds) (2015): The Hungarian Labor Market 2015. Budapest, IE-CERSHAS.

Finchelstein, F. (2014): Returning Populism to History. Constellations, 21(4): 467-482.

Freedom House (2016): Nations in Transit. Hungary Report. Washington, D.C.

Freudenberg, Ch. - Berki, T. - Reiff, Á. (2016): A Long-Term Evaluation of Recent Hungarian Reforms. Working Paper, No. 2. Budapest: Magyar Nemzeti Bank.

Gál, R. I. - Iwasaki, I. - Széman, Zs. (eds) (2008): Assessing Intergenerational Equity: An Interdisciplinary Study of Aging and Pension Reform in Hungary. Budapest: Akadémiai Kiadó.

Granseth, E. - Keck, W. - Nagl, W. - Simonovits, A. - Tir, M. (2016): Negative Correlation between Retirement Age and Contribution Length? Budapest: IE-CERS-HAS Working Paper, No. 33.

Guardiancich, I. (2008): How not to Implement: Hungarian Pension Reform in an Institutional Perspective. Warsaw: TIGER Working Paper, No. 110.

Halmai, G. (2017): National(ist) Constitutional Identity? Hungary's Road to Abuse Constitutional Pluralism. Florence: European University Institute, EUI-LAW Working Paper, No. 8.

Hirose, K. (ed.) (2011): Pension Reform in Central and Eastern Europe in Times of Crisis, Austerity and Beyond. Budapest: ILO.

Holtzer, P. (ed.) (2010): Report of the Pension and Old-Age Round Table on Its Activities between March 2007 and November 2009. Budapest: Government of the Republic of Hungary.

Kornai, J. (1995): Eliminating the Shortage Economy. A General Analysis and Examination of the Developments in Hungary. Economics of Transition, 3(1): 13-37 and 3(2): 149- 168. 
Kornai, J. (1996a): Paying the Bill for Goulash-Communism: Hungarian Development and Macro Stabilization in Political-Economy Perspective. Social Research, 63(4): 943- 1040.

Kornai, J. (1996b): Hardening of the Budget Constraint under the Post-Socialist System. Japan and the World Economy, 8: 135- 151.

Kornai, J. (2015): Hungary's U-turn: Retreating from Democracy. Journal of Democracy, 26(3): 34-48. Full version: www.kornai-janos.hu.

Kriesi, H. - Pappas, T. S. (eds) (2015): European Populism in the Shadow of the Great Recession. Colchester, UK: ECPR Press.

Magyar, B. (2016): The Postcommunist Mafia State: The Case of Hungary. Budapest: CEU Press.

Magyar, B. - Vásárhelyi, J. (eds) (2017): Twenty- Five Sides of a Postcommunist Mafia State. Budapest: CEU Press.

Mudde, C. (2004): The Populist Zeitgeist. Government and Opposition, 39(4): 541-563.

Mudde, C. - Kaltwasser, C. R. (2017): Populism: A Very Short Introduction. Oxford and New York: Oxford University Press.

Mulligan, C. B. - Gil, R. - Sala-i-Martini, X. (2004): Do Democracies Have Different Public Policies than Nondemocracies? Journal of Economic Perspectives, 18(1): 51-74.

Müller, J. W. (2016): What is Populism? Philadelphia: University of Pennsylvania Press.

Oblath, G. (2016): Economic Policy and Macroeconomic Developments in Hungary, 2010-2015. Seminar Proceedings, 143. Warsaw: Case.

ONYF (2012-2016): ONYF Statistical Yearbook, 2011- 2015 (in Hungarian). Budapest: Central Administration of National Pension Insurance (CANPI).

Pirro, A. L. P. (2015): The Populist Radical Right in Central and Eastern Europe. London: Routledge.

Sachs, J. (1989): Social Conflict and Populist Policies in Latin America. National Bureau of Economic Research Working Paper, No. 2897. Cambridge, MA.

Simonovits, A. (1999): The New Hungarian Pension System and its Problems. In: Müller, K. - Ryll, A. - Wagener, H. J. (eds): Transformation of Socials Security: Pensions in Central-Eastern Europe. Heidelberg: Physica, pp. 211-230.

Simonovits, A. (2011): The Mandatory Private Pension Pillar in Hungary: An Obituary. International Social Security Review, 64(3): 81-98.

Simonovits, A. (2018): The Best Indexation of Public Pensions: The Point System. Budapest: IECERS-HAS Working Paper, No. 15.

Simonovits, A. (2019): The Boomerang of Female40: Seniority Pensions in Hungary, 2011-2018 (accepted in European Journal of Social Security).

Szikra, D. (2014): Democracy and Welfare in Hard Times: The Social Policy of the Orbán Government in Hungary between 2010 and 2014. Journal of European Social Policy, 24(5): 486500.

Tóth, G. A. (ed.) (2011): Constitution for a Disunited Nation. On Hungary's 2011 Fundamental Law. Budapest: CEU Press.

Vanhuysse, P. (2006): Divide and Pacify: Strategic Social Policy and Political Protest in PostCommunist Democracy. Budapest: CEU Press.

Vörös, I. (2015): Hungary's Constitutional Evolution during the Last 25 Years. Südosteuropa, 63(2): $173-200$.

World Bank (1994): Averting the Old Age Crisis: Policies to Protect the Old and Promote Growth (Policy Research Report). Oxford: Oxford University Press.

World Bank (2006): Pension Reforms and the Development of Pension Systems: An Evaluation of World Bank Assistance. Washington, D.C.: Independent Evaluation Group. 


\section{APPENDIX}

\section{PENSION INDEXATION BETWEEN 1993 AND 2018}

The latest economic history of Hungary is a good illustration of turmoil. Table A.1 presents the annual growth rates of GDP $\left(g_{y}\right)$, real wages $\left(g_{w}\right)$ and real pensions $\left(g_{b}\right)$ in Hungary during 1993-2018. We include the replacement ratio as well, being the ratio of average benefit to average net wage: $\beta_{t}=b_{t} / v_{t}$. Rather than commenting on the quite erratic GDP and real wage dynamics, we confine our attention to the even more chaotic pension dynamics. There were three phases of indexation in Hungary: wage, combined wage-price and price-indexed as in Table A.1. There were years when the indexation rules were followed, for example in 1993, 2001 and 2011-2012. As the comments of the last column show, in addition to these changes, there were important discretionary measures overwriting rules, due to the elections (denoted by $E$ ), the introduction (2003-2006) and elimination (2009-2010) of the $13^{\text {th }}$ month benefits, and the overestimation of inflation resulting in over-indexation (2013-2015), respectively. The over-indexation in year $t$ is defined as $g_{b}-1$ in the years of price indexation.

To obtain some statistical indicators, first we report the arithmetic averages of the growth factors:

$$
\mathbf{E} g_{y}=1.021, \mathbf{E} g_{w}=1.018 \text { and } \mathbf{E} g_{b}=1.019 \text {. }
$$

(The more appropriate geometric averages hardly differ: 1.02, 1.017 and 1.018, respectively).

Second, we present the standard deviations of the three growth rates, which are quite high:

$$
\mathbf{D} g_{y}=0.026, \mathbf{D} g_{w}=0.054 \text { and } \mathbf{D} g_{b}=0.050 \text {. }
$$

The standard deviations of the growth rates of real wages and of the real benefits are close to each other and twice that of the output.

Third, we display the correlation coefficients of the three variables:

$$
\rho\left(g_{y}, g_{w}\right)=0.559, \rho\left(g_{w}, g_{b}\right)=0.879 \text { and } \rho\left(g_{y}, g_{b}\right)=0.681 \text {. }
$$

All the three coefficients are positive and quite strong. The strength of the first is weaker than the second, and the third lies between them. 
Table A.1. Output, real wage and real pension dynamics, Hungary, 1993-2018

\begin{tabular}{|c|c|c|c|c|c|}
\hline \multirow[t]{2}{*}{ Year } & \multicolumn{3}{|c|}{ Growth rate } & \multirow{2}{*}{$\begin{array}{c}\text { Average } \\
\text { replacement rate }\end{array}$} & \multirow[t]{2}{*}{ Comments } \\
\hline & GDP & Net wage & Pension & & \\
\hline \multicolumn{6}{|c|}{\begin{tabular}{|l|} 
Wage indexation \\
\end{tabular}} \\
\hline 1993 & -0.8 & -3.9 & -4.6 & 0.603 & \\
\hline 1994 & 3.1 & 7.2 & -4.7 & 0.594 & E: change in PIT \\
\hline 1995 & 1.5 & -12.2 & -10.1 & 0.619 & change in delay \\
\hline 1996 & 0.0 & -5.0 & -7.9 & 0.593 & \\
\hline 1997 & 3.3 & 4.9 & 0.4 & 0.563 & \\
\hline 1998 & 4.2 & 3.6 & 6.2 & 0.578 & $\mathrm{E}$ \\
\hline 1999 & 3.1 & 2.5 & 2.1 & 0.592 & \\
\hline \multicolumn{6}{|c|}{ Swiss indexation (half wage + half price) } \\
\hline 2000 & 4.2 & 1.5 & 2.6 & 0.591 & \\
\hline 2001 & 3.8 & 6.4 & 6.6 & 0.591 & + raise \\
\hline 2002 & 4.5 & 13.6 & 9.8 & 0.573 & $\mathrm{E}++$ raise \\
\hline 2003 & 3.8 & 9.2 & 8.5 & 0.568 & +1 week pension \\
\hline 2004 & 4.9 & -1.1 & 3.9 & 0.600 & +2 weeks pension \\
\hline 2005 & 4.4 & 6.3 & 7.9 & 0.611 & +3 weeks pension \\
\hline 2006 & 3.8 & 3.6 & 4.5 & 0.623 & $\mathrm{E}+4$ weeks pension \\
\hline 2007 & 0.4 & -4.6 & -0.3 & 0.668 & \\
\hline 2008 & 0.8 & 0.8 & 3.4 & 0.691 & \\
\hline 2009 & -6.6 & -2.3 & -5.7 & 0.672 & no 13th month: part 1 \\
\hline \multicolumn{6}{|c|}{ Price indexation } \\
\hline 2010 & 0.7 & 1.8 & -0.9 & 0.651 & $\mathrm{E}+$ part 2 \\
\hline 2011 & 1.8 & 2.4 & 1.2 & 0.647 & \\
\hline 2012 & -1.7 & -3.4 & 0.1 & 0.670 & \\
\hline 2013 & 1.9 & 3.1 & 4.5 & 0.678 & Over-indexation \\
\hline 2014 & 3.7 & 3.2 & 3.2 & 0.675 & E+ over-indexation \\
\hline 2015 & 2.9 & 4.3 & 3.5 & 0.668 & Over-indexation \\
\hline 2016 & 2.1 & 7.4 & 1.4 & 0.631 & Wage explosion \\
\hline 2017 & 4.1 & 10.2 & 3.0 & 0.583 & Continued \\
\hline $2018 *$ & 4.8 & 8.0 & 2.0 & 0.555 & Continued \\
\hline
\end{tabular}

Source: ONYF (2016: Table 1.3, page 16 and new data from public statistics).

Notes: E: elections. Continued: continued introduction of $13^{\text {th }}$ month benefit.

Open Access. This is an open-access article distributed under the terms of the Creative Commons Attribution 4.0 International License (https://creativecommons.org/licenses/ by/4.0), which permits unrestricted use, distribution, and reproduction in any medium, provided the original author and source are credited, a link to the CC License is provided, and changes - if any - are indicated. (SID_1) 